\title{
Effect of Elevated Temperature on Some Properties of Air-Entrained Steel Fibers Reinforced Concrete
}

\author{
Abdul Hakeem Hamed Ahmad \\ Professor \\ Rana Burhan Abdurrahman \\ assistant lecturer
}

Civ. Engrg. Dept. / Mosul Univ.

\begin{abstract}
In this paper, an experimental investigation was conducted to explore the mechanical properties of air entrained steel fibers reinforced concrete (AESFC). The residual mechanical properties measured include compressive and splitting tensile strengths, modulus of elasticity and (stress - strain) curves. Air-entrained concretes (AECs) were prepared with different steel fibers content $(0,0.4,0.8$, and 1.2) \% added to enhance the strength of concrete. After exposure to high temperature included $(200,400,600) \circ \mathrm{C}$, the residual mechanical properties of AESFC were investigated and compared with normal concrete. Test results showed reduction in properties by different ratio for all types of concrete after exposure to elevated temperature, the tensile strength and elastic modulus deteriorated with temperature more than the compressive strength. Using steel fibers seems effective in minimizing the degradation of strength for the concrete. Results showed also that the decrease in compressive strength after exposure to high temperature could be reduced by increasing volume of samples. Heating accompanied with weight losses and color changes became clearer at $(400-600){ }^{\circ} \mathrm{C}$ exposure.
\end{abstract}

Key words: Air entrained concrete; steel fibers ; elevated temperature

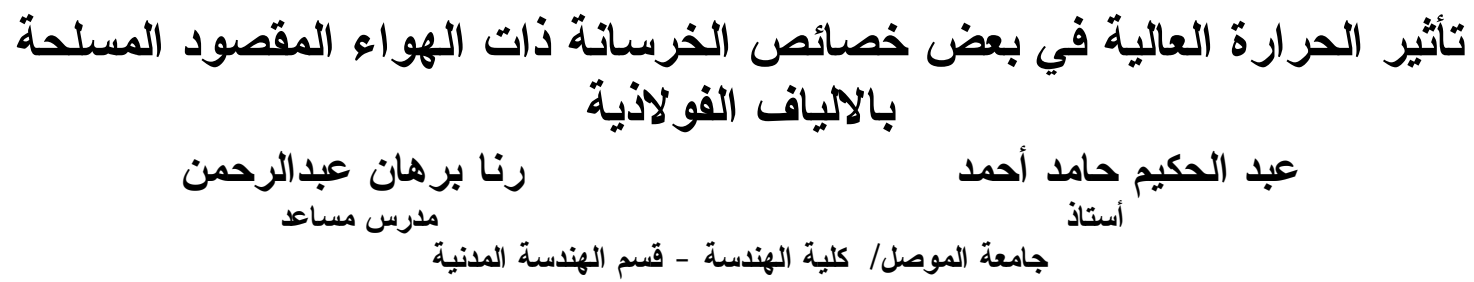

الخلاصة

اشتنمل البحث على در اسة عملية لبعض الخصائص الميكانيكية التي تضمنت مقاومة الانضغاط، الثد الانشطاري،

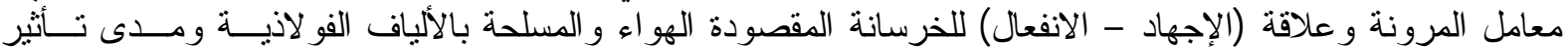

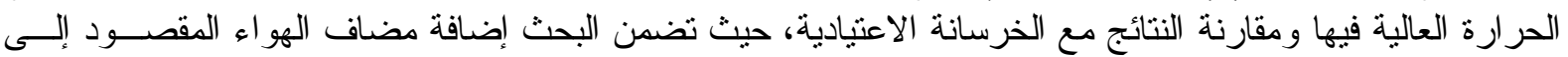

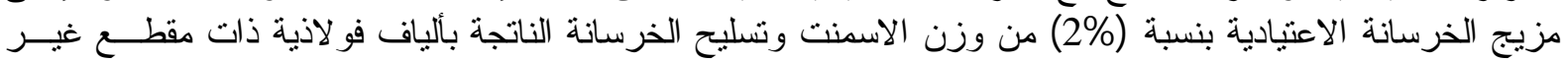

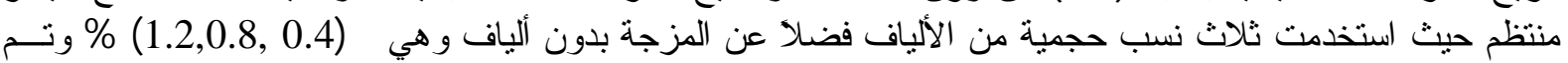

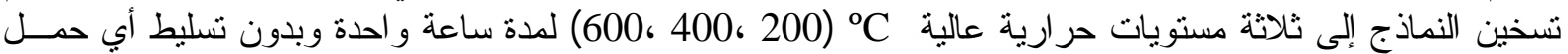
أثناء التسخين.

بعد التعرض للحر ارة العالية انخفضت الخصائص الميكانيكية بصورة سلبية وبنسب مختلفة للمزجات جميعًا وكان

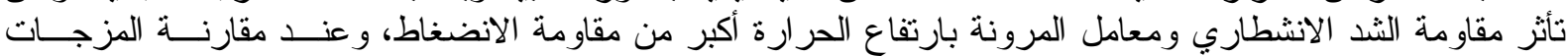

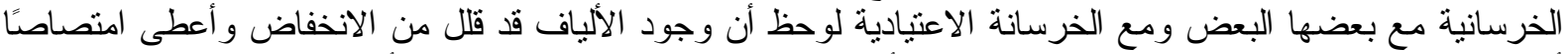

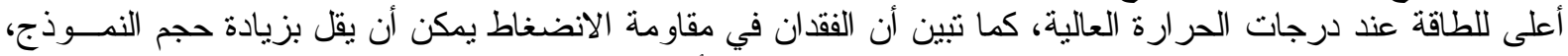

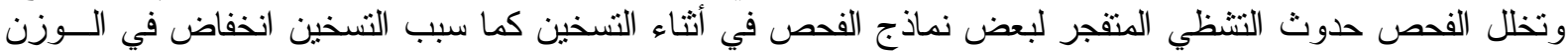

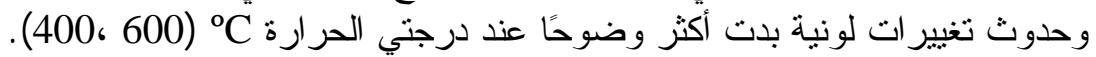




\section{$\begin{array}{llll}\text { Al-Rafidain Engineering } & \text { Vol.17 } & \text { No.4 } & \text { August } 2009\end{array}$}

\section{Introduction}

Today concrete has been used with an increased strength and durability in connection with the developments in technology in pre-stressed concrete, concrete and reinforced concrete structures. It has become practice to entrain a percentage of air in concrete (AEC) to improve its durability and in particular its resistance to frost attack. Entrained air also improves the concrete workability and makes it easier to be compacted, placed and finished by the presence of minute air bubbles dispersed uniformly throw the cement-paste portion of the concrete. Air-entrainment usually reduces strength; the reduction is generally proportional to the amount of air entrained. Therefore, while a proper air-voids system must be provided, excessive amount of air must be avoided [1].

Steel fiber concrete (SFC) have been used in the last five decades to improve the performance refractory concrete in many application and other properties [2].

Pre-stressed concrete, concrete and reinforced concrete structures are sometimes exposed to fires and many structures become damaged and/or out of use [3]. As it is known, high temperatures caused as a result of fire, decreases the concrete strength and durability of such structures. Fire resistance of concrete is affected by factors like: type of aggregate and cement used in its composition, the temperature and duration of the fire, sizes of structure members, and moisture content of concrete [3-4].

The effects of high temperature on the mechanical properties of concrete have been investigated since the 1940s [5-6]. These studies examined the behavior of cement paste, mortar, concrete samples and reinforced concrete members exposed to high temperature. Results of these studies constituted the technical basis for the provisions and recommendations for determining concrete strength of elevated temperature in many codes [7]. For design purpose, mechanical properties of concrete at elevated temperature may be obtained using design curves prescribed in the codes [8].

The scope of this work is to provide experimental data on the residual mechanical properties of AESFC subject to heat which are important for the safe design of concrete and in the repair of concrete structures.

\section{Experimental details}

\section{1: Materials}

The materials used in this investigation include [9]

- Ordinary Portland cement (PC) comply with the Iraqi standard (IQS 5 - 1984)[10]. The properties of the cement are shown in Table (1),

- River sand comply with the (B.S. 882:1992) [11]with fineness modulus of 2.00, Fig(1) show the sieve analysis of fine aggregate,

- River rounded gravel comply with the (B.S. 882:1992) [11] with max aggregate size 14 $\mathrm{mm}$, Fig(2) show the sieve analysis of coarse aggregate,

- City tap water

- Air entraining agent (Polyurthane Dp 25/1), and

- Shelled deformed section of stainless-steel fibers type with aspect ratio (length / equivalent diameter) of 19.635, $16 \mathrm{~mm}$ in length. 
Ahmad : Effect of Elevated Temperature on Some Properties ofAir-Entrained Steel

Table 1: Properties of cement

Chemical Analysis of cement*

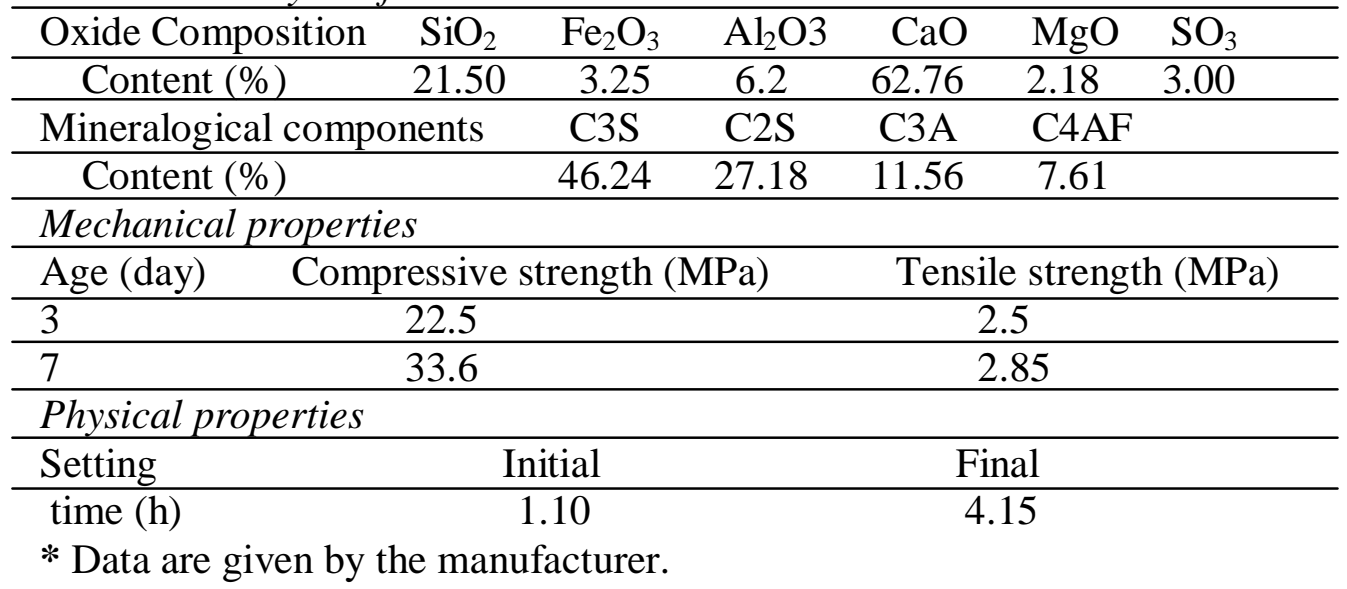

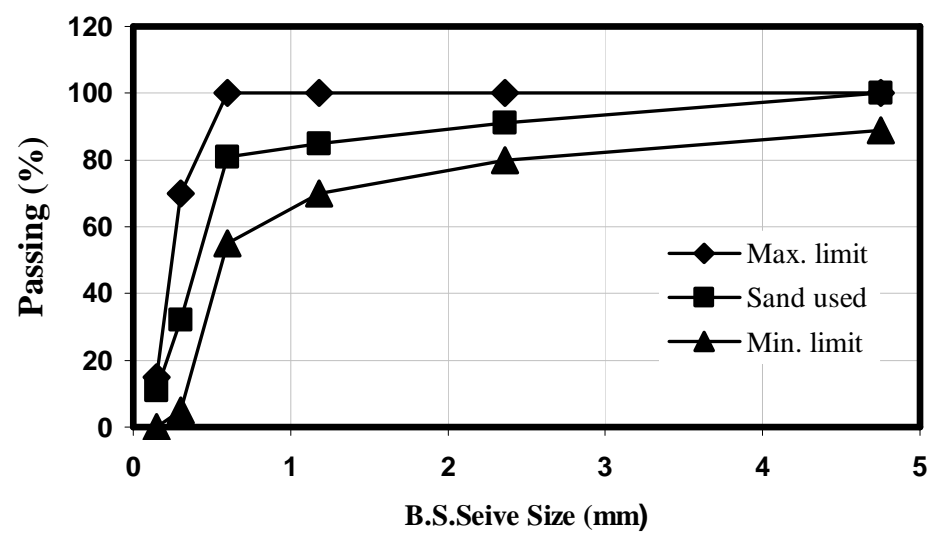

Fig (1): Sieve analysis of fine aggregate

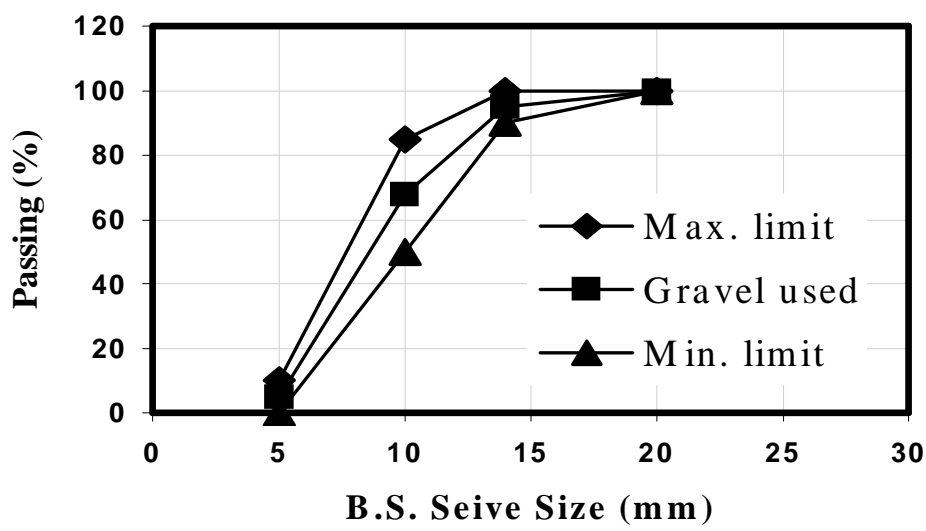

Fig (2): Sieve analysis of coarse aggregate 


\section{2: mixture proportion}

A total of five concrete mixtures were prepared include plain concrete, air entrained concrete and three steel fibers air entrained concrete mixtures that were prepared with 0.4,0.8 and $1.2 \%$ (by volume) of steel fibers, The percentage were based on the total volume of the concrete, all the concrete mixtures were prepared with a water to cement ratio of 0.47 . The details of the mix proportions are shown in Table (2).

Table 2: Concrete mixes designed for test

\begin{tabular}{|c|c|c|c|c|c|c|}
\hline \multicolumn{7}{|c|}{ Mix proportion $\left(\mathrm{Kg} / \mathrm{m}^{3}\right)$} \\
\hline Mix & Cement & Gravel & Sand & Water & AEAs & SF \\
\hline M1 & 359 & 1257 & 610 & 169 & 0 & 0 \\
\hline M2 & 359 & 1257 & 610 & 169 & 7 & 0 \\
\hline M3 & 359 & 1257 & 610 & 169 & 7 & 32 \\
\hline M4 & 359 & 1257 & 610 & 169 & 7 & 64 \\
\hline M5 & 359 & 1257 & 610 & 169 & 7 & 96 \\
\hline
\end{tabular}

\section{3: Specimen preparation and testing program}

Dry cement and aggregate were mixed for one minute in a vertical rotating concrete flow mixer, mixing was continued for a further minute while water was added. The AEAs was then added in 3 minute. The fibers were then finally fed continuously to the mixer for a period of 2 to5 mins depending upon the fibers content and homogeneity of the mixture[2].

For each mixture, a total of 36 specimens, including twelve $100 \mathrm{~mm}$ cubes, twelve $(100 \times 200) \mathrm{mm}$ cylinders and twelve $(150 \times 300) \mathrm{mm}$ cylinders, were cast in steel molds, a vibration table was used to consolidate the concrete. The specimens, after removal from the steel molds at one day, were cured in water for 14 days, after wet curing, they were air dried in the laboratory for 14 days before exposing to elevated temperature.

Specimens were heated in an electric furnace to different temperature of 200,400 and $600{ }^{\circ} \mathrm{C}$. Temperature - Time curve of the test with a target temperature of $600{ }^{\circ} \mathrm{C}$ is given in Fig. (3), the target temperature was maintained for one hour, after that, the specimens were allowed to cool down naturally to room temperature inside the furnance[9].

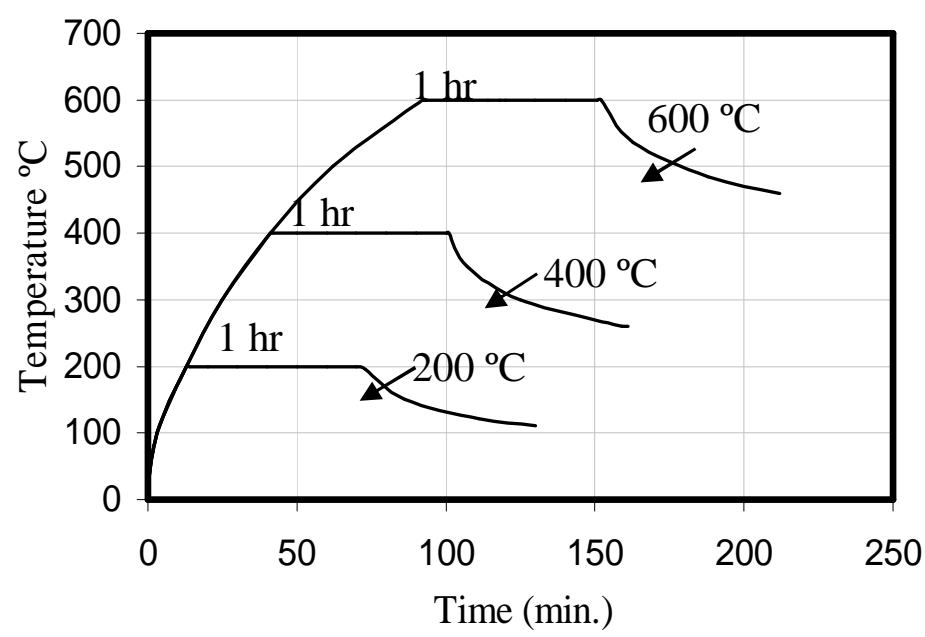

Fig (3) Temperature - Time curve 
Residual mechanical properties were then determined including compressive and tensile strength according to (BS 1881: Part 116)[12] and (ASTM C496)[13] respectively and elastic modulus according to (ASTM C469)[14].

\section{Results and Discussion}

\section{1: Weight loss and surface colour}

The weight of the cube specimens before and after exposure to high temperature was determined, respectively for the weight loss evaluation. The weight losses at elevated temperature of all the investigation mixtures are presented in Fig.(4) for different elevated temperature.

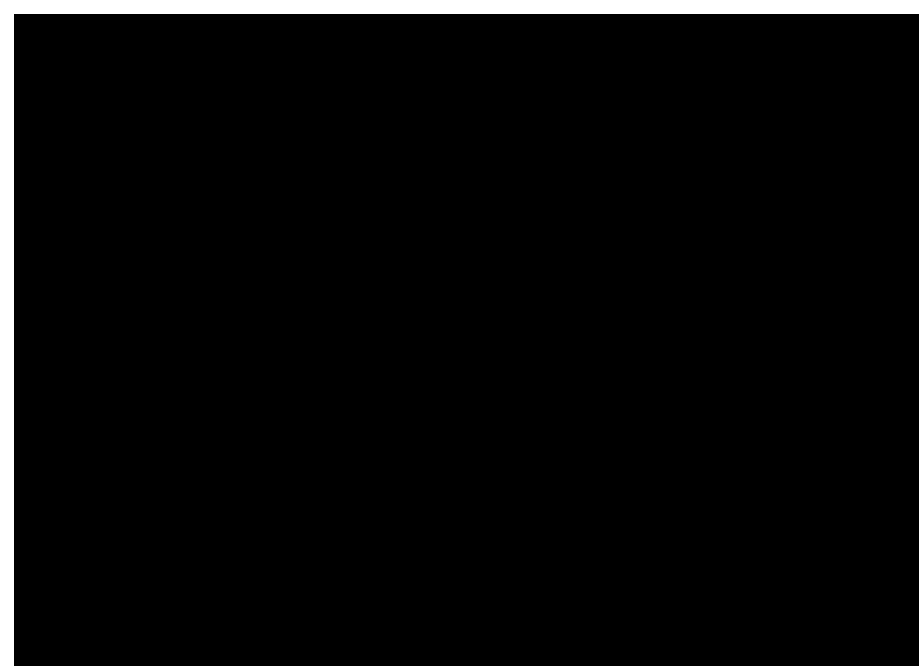

Fig (4) Weight losses of concrete cube specimens

With the increase of exposed temperature the concrete showed increased weight losses, it is clear that the normal concrete exhibits less weight loss than the AESFC because of the lower consistency and more closed separated voids containing free water inside than normal concrete.

The change in concrete colour can be attributed to the change in texture and composition, expansion and crystal destruction during a fire [15]. At the temperature of $200{ }^{\circ} \mathrm{C}$, there was no apparent visual discoloration occurred in the concrete. When temperature increased to 600 ${ }^{\circ} \mathrm{C}$ the concrete specimen suffered noticeable colour changes. Fig. (5) Present the surface color and micro cracks of specimen at $600{ }^{\circ} \mathrm{C}$.

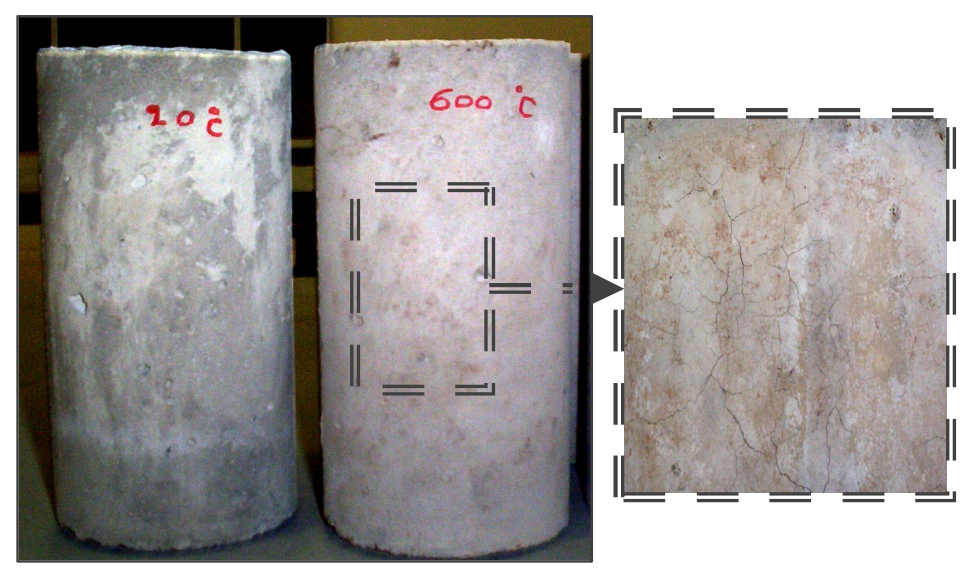

Fig (5) Color surface and micro cracks at $600 \circ \mathrm{C}$. 


\section{2: Compressive strength}

Compressive strength tests are done on the concretes samples. The average compressive strength are given in Table (3) .Entrained air is added to the mix without any other changes in the mix proportions being made, voids caused by entrained air will affect the density and strength in the same way as voids of any other source[16], Decrease in compressive strength caused by entrained air is about $16.38 \%$ at normal temperature .

Table 3: Temperature effect on Compressive strength of concrete mixes

\begin{tabular}{|c|c|c|c|c|c|}
\hline \multicolumn{7}{|c|}{ Compressive Strength (MPa) } \\
\hline Mix & M1 & M2 & M3 & M4 & M5 \\
\hline Tem. ${ }^{\circ}$ C & $f_{\text {cu, } \mathrm{m}}$ & $f_{\text {cu, } \mathrm{m}}$ & $f_{\text {cuf }, \mathrm{m}}$ & $f_{\text {cuf }, \mathrm{m}}$ & $f_{\text {cuf }, \mathrm{m}}$ \\
\hline $\mathbf{2 0}$ & 37.92 & 31.71 & 33.50 & 35.30 & 32.36 \\
\hline $\mathbf{2 0 0}$ & 31.05 & 24.35 & 25.66 & 27.13 & 25.34 \\
\hline $\mathbf{4 0 0}$ & 28.93 & 25.17 & 26.48 & 27.30 & 26.15 \\
\hline $\mathbf{6 0 0}$ & 18.14 & 17.32 & 18.96 & 20.26 & 19.77 \\
\hline
\end{tabular}

The development of compressive strength of AESFC at various volume fraction and temperature is shown in Fig. (6), compared to AEC the strength of AESFC improved with increasing the volume fraction, improvment at room temperature ranged from $5.64 \%$ at $0.4 \%$ fraction and expanded to $11.32 \%$ at $0.8 \%$ fraction, then dropped to $2.05 \%$ at $1.2 \%$ fraction, this might be due to the insufficient dispersing of the fibers in the concrete during mixing. Improvement continuous with the increase of exposure temperature, so at $600 \circ \mathrm{C}$ the improvement ranged from $9.47 \%$ for $0.4 \%$ fraction, expanded to $16.97 \%$ at $0.8 \%$ fraction and $14.15 \%$ at $1.2 \%$ fraction, Steel fibers are seen to be useful in minimizing the damage effect of high temperature for all concrete mixes, Since steel fibers are uniformly dispersed in the segment, cracks occurred and width of cracks is smaller than that of normal segment $[17,18]$.

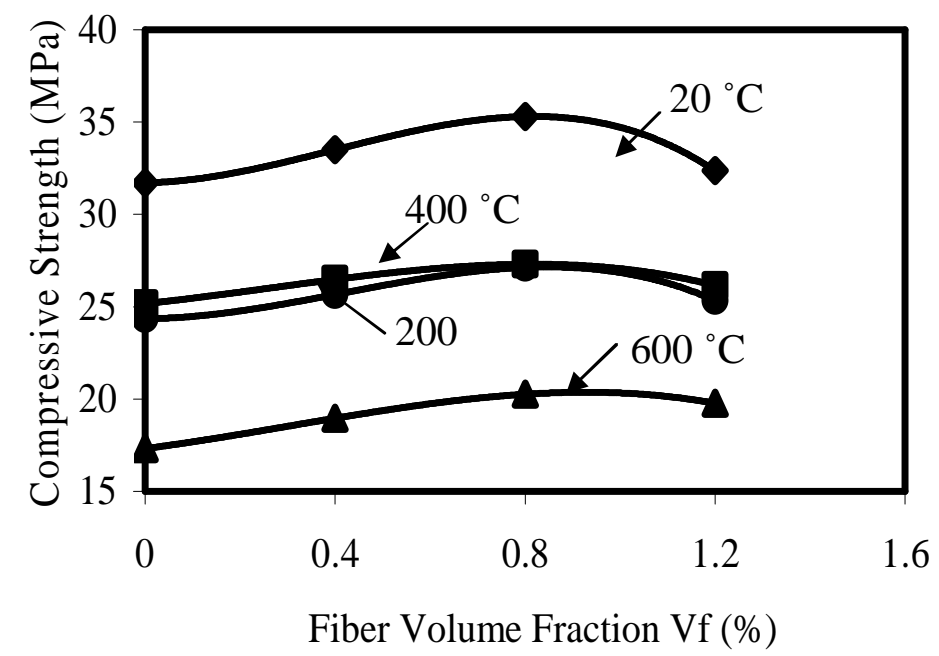

Fig (6) Compressive strength of AESFC at various volume fraction and temperature 
The compressive strength after heating at different temperature was expressed as a percentage of the compressive strength of normal concrete at $20^{\circ} \mathrm{C}\left(f_{\mathrm{cu}}(\mathrm{T}) / f_{\mathrm{cu}} \mathrm{M} 1(20)\right)$ as shown in Fig.(7).

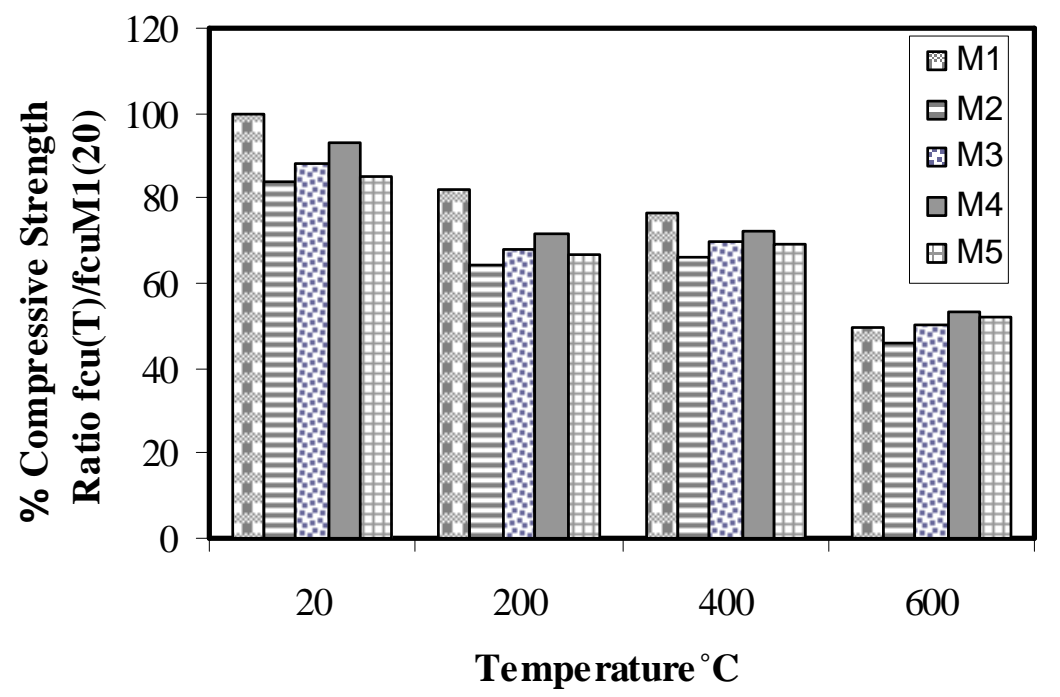

Fig.(7) \% Compressive strength Ratio for concrete mixes at elevated temperature

As concluded from Fig.(7) is can be seen that $0.8 \%$ fraction give more effective residual compressive strength in different temperature than the other mixes of AESFC.

It has been found that the compressive strength of the concrete mixes is decreasing with temperature increase. Also, found that the increases in temperature from 200 to $400{ }^{\circ} \mathrm{C}$, concretes have recovered some of its compressive strength, this gain was quite strange and may be attributed to some hydration of the cement paste at this temperature that did not occur at lower temperatures [19,20]. After $400 \circ \mathrm{C}$ the compressive strength drop off dramatically for all mixes. Although there are different approaches to explain the occurrences, causing loss of compressive strength when exposed to high temperature. The problem informing a model is investigated by taking thermal incompatibility between cement paste and aggregate, contact between aggregate and cement paste interface, the pressure of evaporated water during heating, and chemical structure changes in cement paste and aggregates into consideration [21]. Shrinkage caused by evaporation of water and steam pressure occurring in concrete causes cover concrete to crack and break off. As a result of the destruction of concrete, $\mathrm{Ca}(\mathrm{OH}) 2$, one of the most important compounds in cement paste, turns into $\mathrm{CaO}$ at $530{ }^{\circ} \mathrm{C}$. During this process, an almost 33\% shrinkage happens. When the water is sprayed in order to extinguish fire, $\mathrm{CaO}$ turns into $\mathrm{Ca}(\mathrm{OH}) 2$ and flows through the pores and forms white spots on the surface after the fire. This leads to a volume increase of $44 \%$. During these processes, some cracks occur and concrete is crumbled and becomes porous material [22]. Aggregate's effect on concrete at high temperatures is related to their mineral structures. This process results in volume increase and damage [23].

Figs. $(8,9)$ show the comparison of residual compressive strength of M1 and M4 with four specimens size of 100 and $150 \mathrm{~mm}$ cubes and $100 \times 200$ and $150 \times 300 \mathrm{~mm}$ cylinders. Because of explosive spalling of specimen $150 \times 300 \mathrm{~mm}$ when it subjected to $600{ }^{\circ} \mathrm{C}$, compressive 


\section{$\begin{array}{lllll}\text { Al-Rafidain Engineering } & \text { Vol.17 } & \text { No.4 } & \text { August } 2009\end{array}$}

strength computed at $500{ }^{\circ} \mathrm{C}$. It can be seen that the compressive strength is affected by specimen size after high temperature. The larger the specimen size is, the lesser the strength loss becomes. Concrete is weak in heat condition; therefore, there exists a temperature distribution field inside concrete specimens during heating consequently, the temperature in the center of the concrete is much lower than that on the exposed surface. Therefore, under the same condition, the compressive strength loss of the concrete specimen with a larger cross section is smaller.

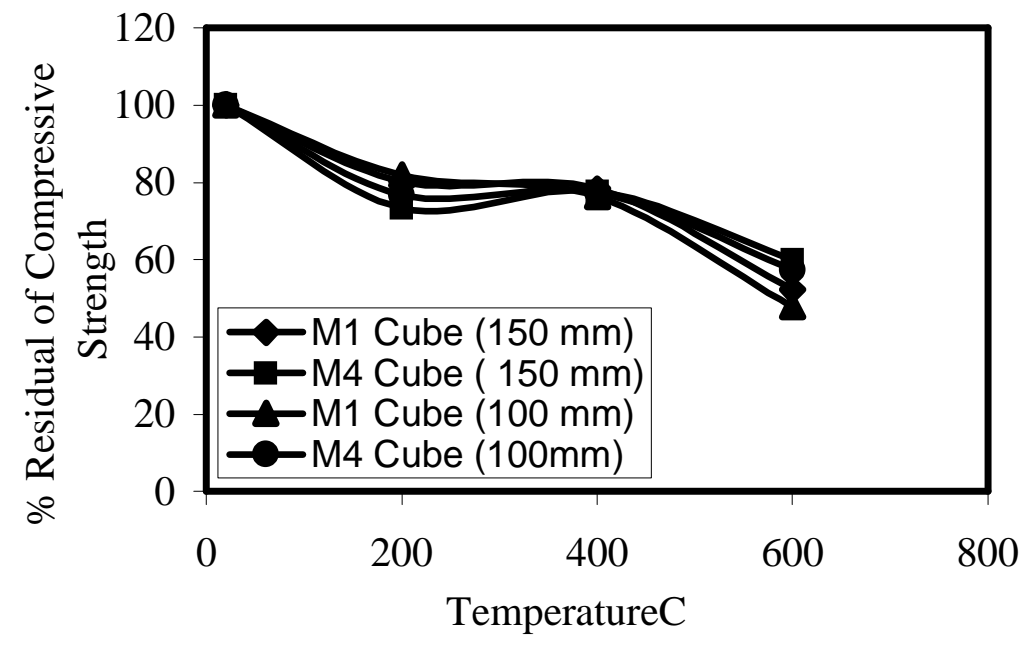

Fig. (8) Residual compressive strength of M1 and M4 with two specimens size of cubes

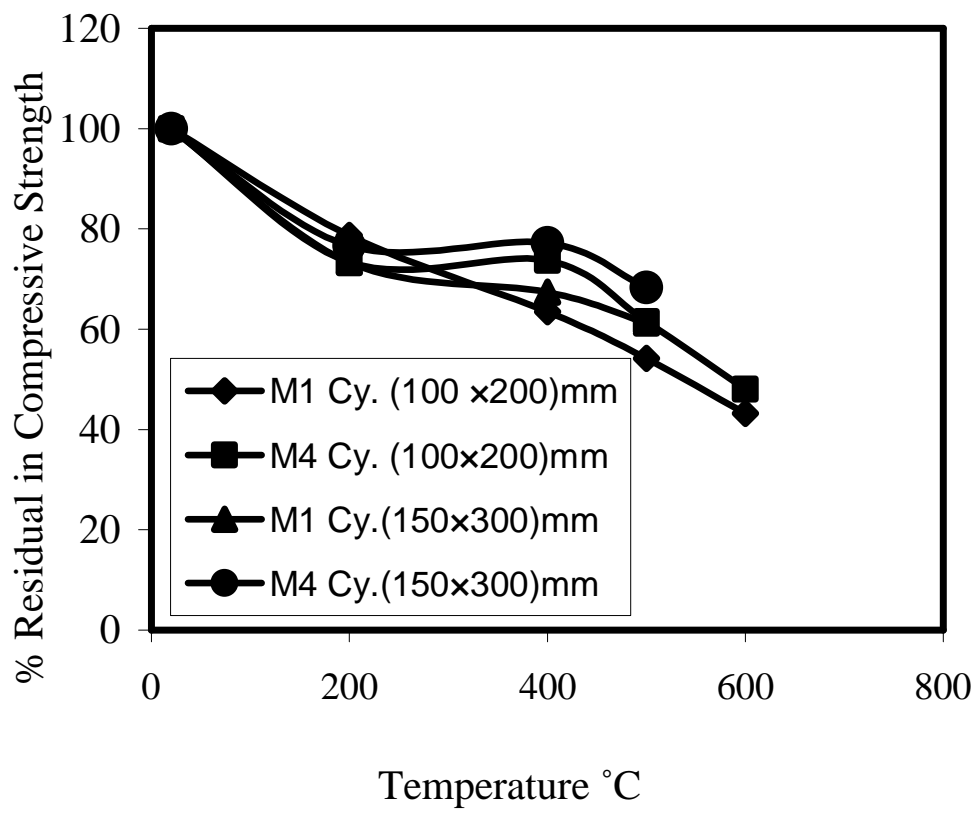

Fig. (9) Residual compressive strength of M1 and M4 with two specimens size of cylinder 


\section{3: Splitting tensile strength}

The average tensile strength for different mixes is given in Table (4). The decrease in tensile strength in AEC (M2) compare with plain concrete is $9.97 \%$ at room temperature caused by entrained air; voids caused by entrained air affect the tensile strength in the same way as compressive strength.

Table 4: Temperature effect on tensile strength of concrete mixes

\begin{tabular}{|c|c|c|c|c|c|}
\hline \multicolumn{7}{|c|}{ Tensile Strength (MPa) } \\
\hline Mix & M1 & M2 & M3 & M4 & M5 \\
\hline Tem. $^{\circ} \mathbf{C}$ & $f_{\mathrm{t}, \mathrm{m}}$ & $f_{\mathrm{t}, \mathrm{m}}$ & $f_{\mathrm{tf}, \mathrm{m}}$ & $f_{\mathrm{tf}, \mathrm{m}}$ & $f_{\mathrm{tf}, \mathrm{m}}$ \\
\hline $\mathbf{2 0}$ & 3.91 & 3.52 & 3.91 & 4.16 & 4.58 \\
\hline $\mathbf{2 0 0}$ & 3.02 & 2.76 & 3.07 & 3.27 & 3.64 \\
\hline $\mathbf{4 0 0}$ & 2.39 & 2.14 & 2.53 & 2.81 & 3.33 \\
\hline $\mathbf{6 0 0}$ & 1.20 & 0.99 & 1.35 & 1.61 & 1.81 \\
\hline \hline
\end{tabular}

The development of splitting tensile strength of AESFC at various fibers volume fraction and temperature is shown in Fig.(10), compared to AEC the strength of AESFC improved with increasing the volume fraction of fibers, the improved strength at room temperature started from $11.08 \%$ at $0.4 \%$ fraction to $30.11 \%$ at $1.2 \%$ fraction. Improvement increase, with increasing the exposure temperature, at $600{ }^{\circ} \mathrm{C}$ the improved strength started from $36.36 \%$ at $0.4 \%$ fraction to $82.83 \%$ at $1.2 \%$ fraction.

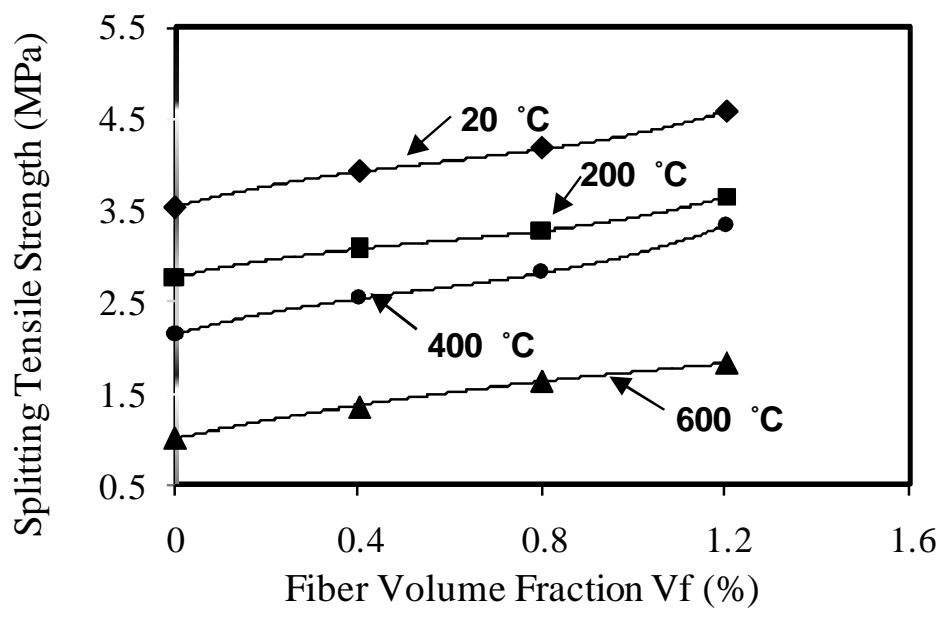

Fig (10) Splitting tensile strength of AESFC at various fibers volume fraction and temperature

Fiber addition in concrete leads to a better control of its cracking. The durability of the material depends on the performance of the bridging capacity of the fibers embedded in the concrete[17].

Fig.(11) shows the tensile strength for concrete mixes at elevated temperature, similar to compressive strength, the tensile strength showed significant losses with the increase in 


\section{$\begin{array}{lllll}\text { Al-Rafidain Engineering } & \text { Vol.17 } & \text { No.4 } & \text { August } 2009\end{array}$}

exposure temperature, the residual tensile strength of fiber reinforced concrete was higher than that of plain concrete for all heating temperature, the reduction might be due to the formation of tensile stresses during the contraction of the hardened cement paste upon cooling, which when superimposed on to the already existing tensile stresses formed during heating would cause an increase in the amount and rate of crack formation [24]

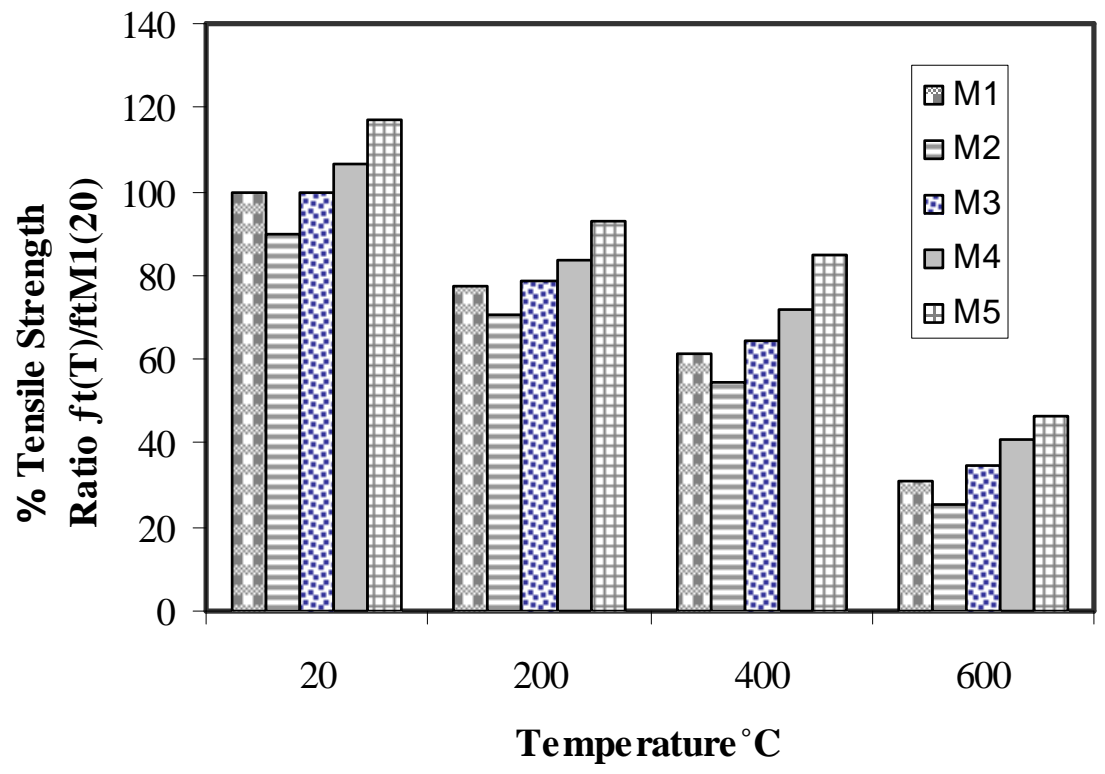

Fig.(11) \% Tensile strength Ratio for concrete mixes at elevated temperature

\section{4: Elastic modulus}

Explosive spalling occurred for all five mixtures of concrete specimens $(150 \times 300 \mathrm{~mm}$ cylinders) subjected to $600{ }^{\circ} \mathrm{C}$; therefore the elastic modulus is computed at $500{ }^{\circ} \mathrm{C}$ instead of $600{ }^{\circ}$ C. Fig. (12) shows the explosive spalling for AESFC sample at $1.2 \%$ fiber fraction. Some previous reports $[19,25]$ proved that explosive spalling is significantly associated with internal cracking, it was also explained that rapid heating of concrete specimen could cause internal cracks due to stresses that developed when temperature difference between the core and the surface of a specimen exceeded a certain value [26].
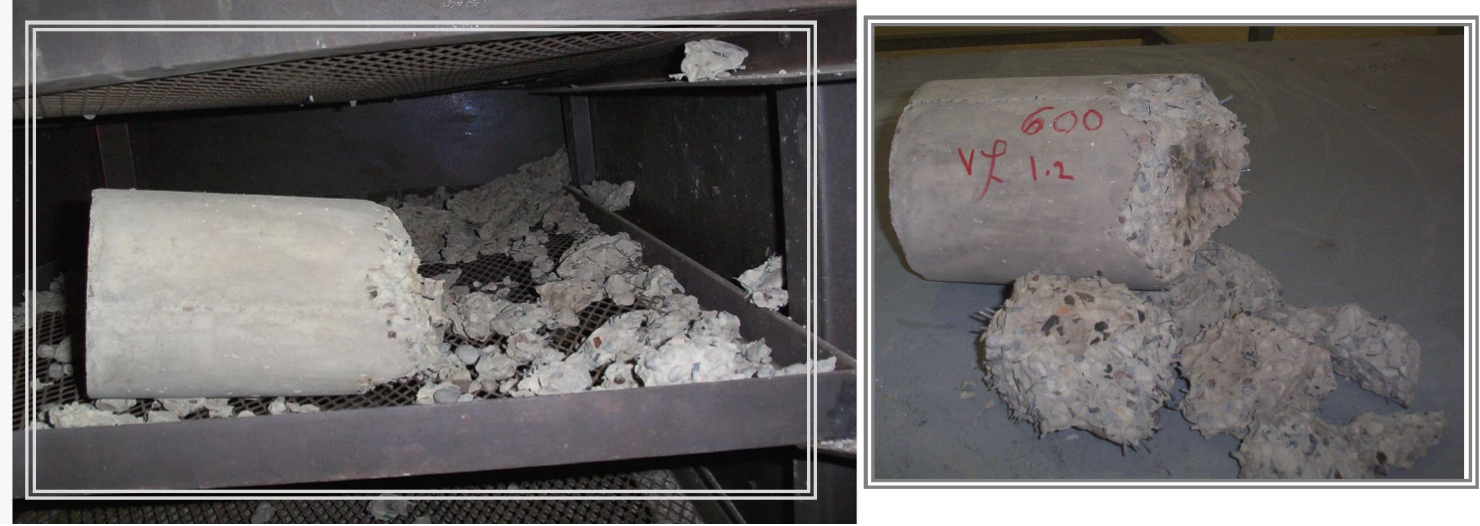

Fig. (12) Explosive spalling 
Table (5) shows the test results for elastic modulus. After exposure to elevated temperature, elastic modulus was decreased with the increase of temperature. Fig (13) shows the residual modulus of elasticity for all five concrete mixes after heating, up to $400{ }^{\circ} \mathrm{C}$ the elastic modulus of all mixtures decrease in a similar fashion, the extent decrease in elastic modulus of plain concrete is higher than that of AESFC at $500{ }^{\circ} \mathrm{C}$. The decrease in elastic modulus was due to gradual deterioration of the binding matrix with a rise in temperature. The transformation of the matrix seemed to be purely physical at lower temperature up to 71 ${ }^{\circ} \mathrm{C}$, where small lumps of $\mathrm{CSH}$ gel coalesced together to form a larger deforming gel mass [27]. However, at further higher temperature, chemical transformation of the gel occur where the fairly dense lumps of $\mathrm{CSH}$ gel under went changes to form a loose white matrix that brought about loss of elasticity of concrete.

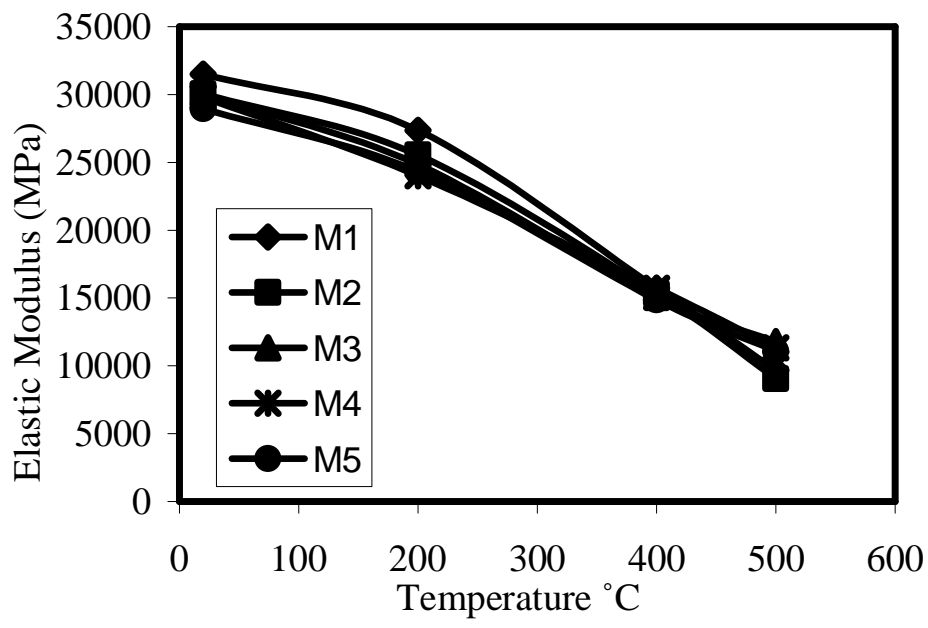

Fig (13): Residual modulus of elasticity

The characterization of concrete strength (Stress-Strain) relationship is used in calculating the resistance of concrete structure. Fig. (14) express stress-strain curves of concrete mixes at test temperature[9].

Table 5: Temperature effect on Elastic Modulus of concrete mixes

\begin{tabular}{|c|c|c|c|c|c|}
\hline \multicolumn{7}{|c|}{ Elastic Modulus (MPa) } \\
\hline Mix & M1 & M2 & M3 & M4 & M5 \\
\hline Tem. $^{\circ} \mathbf{C}$ & $\mathbf{E}_{\mathbf{c}}$ & $\mathbf{E}_{\mathbf{c}}$ & $\mathbf{E}_{\mathbf{c f}}$ & $\mathbf{E}_{\mathbf{c f}}$ & $\mathbf{E}_{\mathbf{c f}}$ \\
\hline $\mathbf{2 0}$ & 31494 & 30059 & 30012 & 29825 & 28941 \\
\hline $\mathbf{2 0 0}$ & 27365 & 25531 & 24838 & 24012 & 24326 \\
\hline $\mathbf{4 0 0}$ & 15706 & 15317 & 15034 & 15722 & 14848 \\
\hline $\mathbf{5 0 0}$ & 9682 & 9053 & 11781 & 11340 & 11091 \\
\hline
\end{tabular}




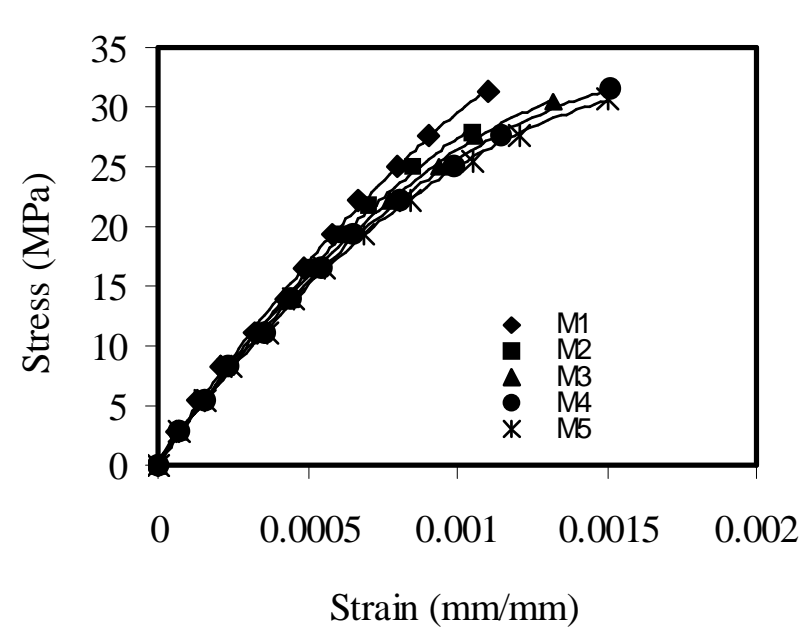

(a) at $20{ }^{\circ} \mathrm{C}$

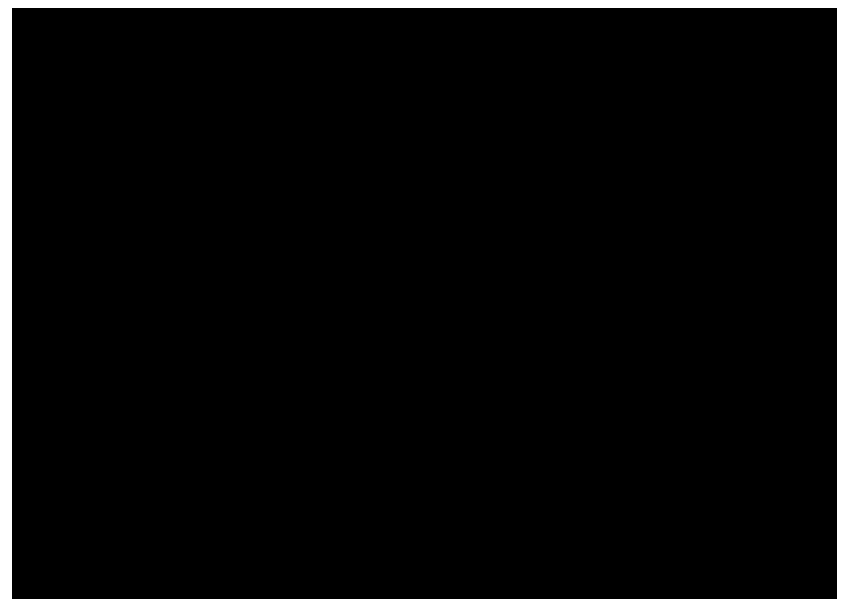

(c) at $400{ }^{\circ} \mathrm{C}$

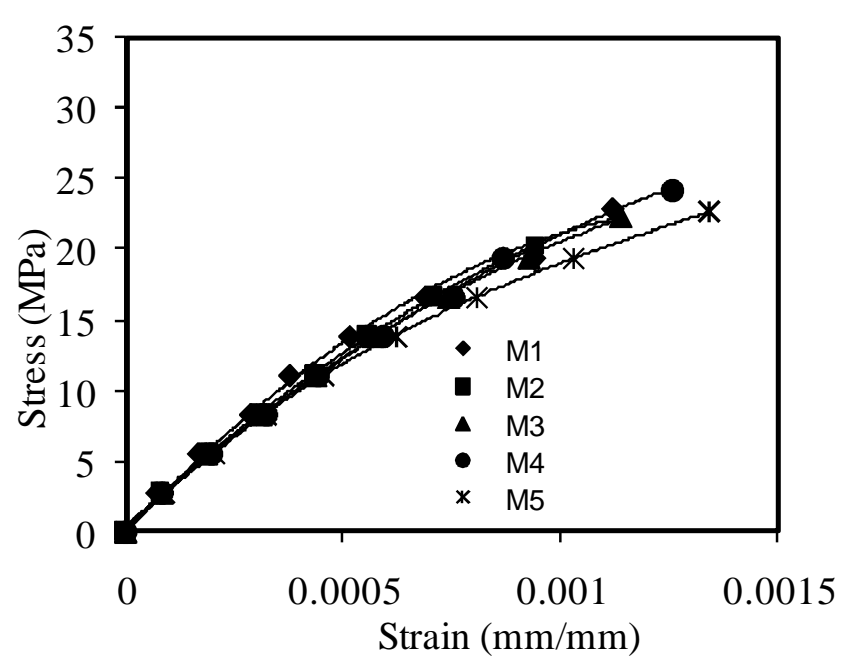

(b) at $200{ }^{\circ} \mathrm{C}$

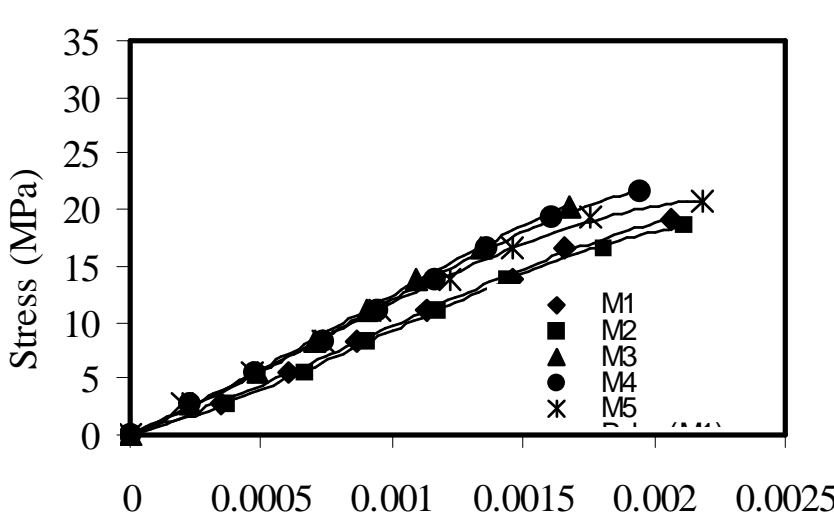

(d) at $500{ }^{\circ} \mathrm{C}$

\section{Fig (14): Stress-strain curves of concrete mixes at test temperature}

\section{Conclusions}

Based on the results obtained in this study, and within the limitation of the test parameters, the following conclusions can be drawn:

- The compressive strength of AEC improved with additions of steel fibers at various volume fractions, the strength showed maximum at $0.8 \%$ fraction but slight decrease at $1.2 \%$ fraction compared to $0.8 \%$.

- The presence of steel fibers has little influence on the elastic modulus; at $500{ }^{\circ} \mathrm{C}$ steel fibers has moderate influence on the variation of elastic modulus.

- Mechanical properties suffer from continuously thermal degradation throughout the temperature range test, steel fibers effective in minimizing the degradation of strength.

- Splitting tensile strength and elastic modulus deteriorated with temperature more than compressive strength.

- Color changes were observed on concrete under the effect of high temperature.

- It has been observed that some samples spall explosively at temperature more than $500{ }^{\circ} \mathrm{C}$ and it has been seen that the cause for such explosive spalling is speed rate of heating. 


\section{References}

[1] Du, L. and Folliard, K.J., "Mechanisms of Air Entrainment in Concrete", Cement and Concrete Research, Vol. 35, 2005, pp.1463-1471.

[2] ACI Committee 544, "Design Consideration for Steel Fiber Reinforced Concrete ", (ACI 544-4R-99), American Concrete Institute, 2002.

[3] Cioni P, Croce P, Salvatore W. "Assessing fire damage to reinforced concrete elements". Fire Safety Journal, 2001;36(2):181-99.

[4] Phan LT, Lawson JR, Davis FL. "Effects of elevated temperature exposure on heating characteristics, spalling, and residual proportion of high-performance concrete". Mater Structure 2001;34(236):83-91.

[5] Diederchs U, Schneider U. "Bond strength at high temperature". Mag Concr Res 1981;33(115):75-84.

[6] Malhotra HL. "The effects of temperature on the compressive strength of concrete". Mag Concr Res 1956;8(3):85-94.

[7] Ako" z F, Yu" zer N, Koral S. "The influence of high temperature on the physical and mechanical properties of ordinary Portland cement and silica fume mortar". Tech Journal Turk Chamber Civ Eng 1995;6(1):919-31.

[8] Phan LT." Fire performance of high-strength concrete: a report of the state-of-the- art". Gaithersburg, Maryland: NISTIR 5934, Building and Fire Research laboratory, National Institute of Standards and Technology; 1996.

[9] Alshahwany, R., "Concrete of Elevated Temperature on Some Properties of Air-Entrained Steel Fibers Reinforced Concrete", A thesis submitted to College of Engineering, Mosul University, Mosul, Iraq, March (2007).

[10] Iraqi Standard Specification No.5 (1984)," Properties of Ordinary Portland Cement", Iraq, 1984.

[11] BS 882-1992,"Aggregate from Natural Source for Concrete", British Standard Institution, 1992.

[12] BS 1881:part116:1983"'Testing of Hardened Concrete", British Standard Institution, 1983.

[13] ASTM C496-04, "Splitting Tensile Strength of Cylindrical Concrete Specimens" ,American Society for Testing and Materials, 2004.

[14] ASTM C469-02, "Static Modulus of Elasticity and Poisson's Ratio of Concrete in Compression", American Society for Testing and Materials, 2002.

[15] Ravindrarajah, R., Lopez, R. and Reslan, H., "Effect of Elevated Temperature on the Properties of High Strength Concrete Containing Cement Supplementary Materials", Center of Built Infrastructure Research, University of Technology, Sydney, Australia, March, 2002, pp. $1-9$.

[16] Neville AM. "Properties of concrete". 3rd ed. Harlow Essex, England: Longman Scientific \& Technical, Burnt Mill (Co-published in the United States with New York: Wiley); 1993.

[17] Swamy, R.N., Al-Taan, S. and Ali, S.A.R., "Steel Fibers for Controlling Cracking and Deflection", Concrete International, August, 1979, pp.41-49.

[18] Song, P.S. and Hwang, S., "Mechanical Properties of High- Strength Steel Fiber-Reinforced Concrete", Construction and Building Materials, Vol. 18, 2004, pp.669-673.

[19] Peng, G., Yang, W., Zhao, J., Liu, Y., Bian, S. and Zhao, L., "Explosive Spalling and Residual Mechanical Properties of Fiber-Toughened High-Performance Concrete Subjected to High Temperature ", Cement and Concrete Research, 2005, pp.1-5. 


\section{$\begin{array}{lllll}\text { Al-Rafidain Engineering } & \text { Vol.17 } & \text { No.4 } & \text { August } 2009\end{array}$}

[20] Khalaf , F. M., DeVenny, A. S., "Performance of Brick Aggregate Concrete at High Temperature ", Journal of Materials in Civil Engineering, Vol.16, No.6, December, 2004, pp.556-565.

[21] M.S. Cu" lfik, "Deterioration of bond between cement paste and aggregate at high temperatures", Bog azic_i University, PhD, Istanbul, Turkey,2001.

[22] M.S. Akman, "Building Damages and Repair Principles", Turkish Chamber of Civil Engineers, Istanbul, Turkey, 2000, Published in Turkish.

[23] H.W. Hayden, W.G. Moffatt, J. Wulff, "The Structure and Properties of Materials", vol. 3, Wiley, USA, 1965.

[24] Kodur, V.K.R. and Sultan, M.A., "Effect of Temperature on Thermal Properties of HighStrength Concrete", Journal of Materials in Civil Engineering, ASCE, Vol. 15, No. 2, April, 2003, pp. $101-106$.

[25] Husem, M.,"The Effect of High Temperature on Compressive and Flexural Strengths of Ordinary and High Performance Concrete", Fire Safety Journal, Vol.41, 2006, pp.155-163.

[26] Xiao, J. and Falkner, H.," On Residual Strength of High-Performance Concrete with and without Fibers at Elevated Temperature", Fire Safety Journal, Vol. 41, 2006, pp.115-121.

[27] Schneider, U., "Concrete at High Temperature”, Fire Safety Journal, Vol. 13, 1988, pp. $55-65$.

تم اجراء البحث في كلية الهندسة - جامعة الموصل 